\title{
Mean Performance of the National and International Coconut Accessions for the Yield Attributing and Nut Quality Traits
}

\author{
G.N. Khadke ${ }^{1}$, V. Niral ${ }^{2}$, M.S. Kulkarni ${ }^{3}$, N.K. Hegde ${ }^{4}$, \\ N. Sandhyarani ${ }^{1}$ and M.B.N. Naika ${ }^{1}$ \\ ${ }^{1}$ College of Horticulture, Arabhavi, UHS, Bagalkot, Karnataka, India \\ ${ }^{2}$ ICAR-CPCRI, Kasaragod, Kerala, India \\ ${ }^{3}$ PGS, University of Horticultural Sciences, Bagalkot, Karnataka, India \\ ${ }^{4}$ College of Horticulture, Sirsi, UHS, Bagalkot, Karnataka, India \\ *Corresponding author
}

\section{Keywords}

Coconut,

Accessions, Cocos,

Arecaceae

Article Info

Accepted:

20 January 2019

Available Online:

10 February 2019

\section{A B S T R A C T}

The mean performance study was carried out in coconut for the growth, yield and nut quality traits of exotic and indigenous coconut accessions which is maintained at ICAR, CPCRI, RC, Kidu. Wide variations on the growth parameters observed in the within the studied accessions. Among the twenty eight accessions, maximum vegetative characters viz., trunk girth at $1.5 \mathrm{~m}$ height of stem in Bari Narikel-II $(102.7 \mathrm{~cm})$, number of functional leaves in Sambava Green Tall (36.1), length of petiole $(172.0 \mathrm{~cm})$ and length of leaflet bearing portion $(464.5 \mathrm{~cm})$ in Comoros Red Tall and number of paired leaflet in King Kumbra Tall (123.2) were recorded. The total bunches on the crown was recorded high in Bari Narikel II (17.6), number of bunches on crown with below fist size fruits (4.0) was high in the Comoros Tall Uzirpur Tall, Bari Narikel II and Sri Lankan Yellow Dwarf II and above fist size was high in Bari Narikel II (13.6). The mean number of fruits below fist size was recorded more in Chinashukania Tall (321.9) and above fist size fruits recorded high in Sambava Green Tall (131.5). The maximum nut characters viz., whole fruit weight (1734.7 gm), per cent of husk to whole nut weight (47.4\%) and fresh endosperm (449 gm) were observed in Guelle Rose Tall and Volume of endosperm cavity was in Sri Lankan Red Dwarf II (339.4 ml). From the study of mean performance of the accessions, it is difficult to postulate a single accessions with all the desirable traits combined together. However, based on growth and various yield attributing traits, the tall accessions Bari Narikel-II, Chandan Nagar Tall, Panama Tall, West Coast Tall, Rupdia Tall and Kayemkola Tall can be grouped as promising for the productivity traits. Hence, this accession can be included in to the further breeding programme to develop the new high yielding variety. 


\section{Introduction}

Coconut (Cocos nucifera L.) is the most extensively grown and used crop in the world. It is referred as King of tropical palms and plays a major role in the economic, cultural and social life of more than 80 tropical countries. It is a diploid with chromosome number of $2 \mathrm{n}=32$ and is traditionally seed propagated with slow growing habit. Purseglove (1968) agreeing with an coconut originated from South East Asia and distributed to many parts of the world including Central and South America, East and West Africa, East Asia and the Pacific Islands. India is the third largest coconut producer after Indonesia and Philippines with total production of 152.56 lakh tonnes from an area of 20.88 lakh hectares. In India, Tamil Nadu, Kerala, Karnataka, Andhra Pradesh and Maharashtra are the major producing states (Anon., 2017). Since coconut is a cross pollinated crop, propagated only through seed, it is highly heterozygous in nature. The dissemination of coconut seeds was achieved through floating in sea currents and subsequent germination on the shore, followed by further human dispersal in various coconut growing countries (Ohler, 1984) and hence the present population differentiation is due the geographic isolation, introgressive hybridization, natural mutation and selection process by human (Perera et al., 2000).

The yield of coconut, being a complex character, is controlled by a number of components and their interaction. Identification of suitable genotypes with superior quality as consumer preference and more number of nuts per palm as farmer's preference will be a favourable step. Hence, coconut accessions, representing indigenous and exotic collection maintained in the ex situ field gene bank at ICAR-CPCRI Research Centre $\mathrm{Kidu}$, are proposed for investigation and characterization of vegetative and nut characters for yield and nut quality.

\section{Materials and Methods}

The uncharacterized and recent twenty five tall types and three dwarf type accessions collected and maintained at ICAR- CPCRI, research Centre, Kidu has been selected for the present study (Table 1). Among the twenty eight coconut accessions, twenty three exotic and five indigenous types were of different geographical origins. The experiment was laid out in a randomized block design (RBD) with 3 replications with each accession representing 2 palms per replication and accessions taken for study were planted at a distance of $7.5 \mathrm{~m} \times 7.5 \mathrm{~m}$. These accessions were of 18-20 years old at the time of this experiment. Recommended package of practices were followed for all the genotypes (Nampoothiri et al., 2000).

According to the standard procedures (Anon, 1995; Ratnambal et al., 1995 and Ratnambal et al., 2000a) the descriptor traits and DUS test traits notified by PPV and FR Authority (Anon, 2011) was recorded for two seasons. Observations were recorded from all the palms representing each accession in each replication on vegetative and nut characters. Observations were recorded twice, once during August-2016 to September 2016 and another between August-2017 to September2017 with one year interval. The two year mean values of all the above quantitative characters of the 28 accessions were subjected to statistical analysis. The mean, standard error of deviation and co-efficient of variation were calculated according to Panse and Sukhatme (1961).

\section{Results and Discussion}

In the present investigation, significant differences were observed growth characters 
like palm trunk girth at $1.5 \mathrm{~m}$ height, total number of leaves on the crown, petiole length, length of leaflet bearing portion and number of paired leaves among the accessions (Table 2).

Among the twenty eight accessions studied, the differences in stem girth are readily noticeable between palms belonging to different accessions. Long (1993) classified the tall and dwarf based on the stem girth and revealed that the tall varieties showed straight and thick stem at base as compared to dwarf types. Higher trunk girth at $1.5 \mathrm{~m}$ height was observed in Bari Narikel-II $(102.7 \mathrm{~cm})$ and followed by Comoros Green Tall $(101.0 \mathrm{~cm})$ whereas; lowest girth $(52.0 \mathrm{~cm})$ was recorded in Coco Bleu Tall.

Annually a palm produces twelve leaves and the number of available functional leaves at a time decides the health of the palms which will reflect on the nut production. Iyer (1980) reported that the increase in trunk height with simultaneous increase in number of leaves contributed to the overall yield of the palm. Regarding the leaf characters viz., number of leaves, length of petiole, length of leaflet bearing portion, number of paired leaflets, length of leaflet, breadth of leaflet among the twenty eight accessions showed noticeable variation amongst themselves. In this study, the average numbers of leaves per palm varied from 23.6 in Coco Bleu Tall and 36.1 in Sambava Green Tall, with a mean value of 28.2 leaves. Generally, the number of leaves was higher in tall accessions than dwarf types. Ratnambal et al., (1995), Renuga (1999), Ratnambal et al., (2000), Ratnambal et al., (2002), Arunachalam et al., (2005), Princy (2013), Samsudeen et al., (2013), Suchithra (2014), Perera et al., (2016a) and Jerard et al., (2017) also reported similar results. Petiole and leaf length an important character, since it decides the ability of the leaf to support bunches in its axils and also the photosynthetic efficiency. Longer the leaf and petiole, the weaker it seems to be and unable to provide ample support to its fruit and bunch. On the other hand, shorter leaves provide adequate support to its bunch (Pieries, 1934). In the present study length of leaf petiole ranged from $90.4 \mathrm{~cm}$ in Coco Bleu Tall and $172 \mathrm{~cm}$ in Comoros Red Tall. The accessions, Bari Narikel-II, Rupdia Tall, Panama Tall and Bagharpara Tall also recorded higher length of petiole. Generally petiole length was higher in tall accessions than in dwarf accessions. Ratnambal et al., (1995), Renuga (1999), Ratnambal et al., (2000), Ratnambal et al., (2002), Jerard (2002), Arunachalam et al., (2005), Samsudeen et al., (2013) and Jerard et al., (2017) also reported similar results.

The length of leaflet bearing portion decides the number of leaflets borne on the leaves. Higher the number of leaflets higher is the yield as reported by Nair and Nampoothiri (1993) and Ratnambal et al., (1995). The greater length of leaflet bearing portion in leaves was registered in the accession Comoros Red Tall, followed by Comoros Green Tall and Bari Narikel-II. The smallest length of leaflet bearing portion was recorded in Sri Lankan Red Dwarf II followed by Coco Bleu Tall in the present study. Among the twenty eight accessions, the mean number of paired leaflets on both sides of the leaves ranged from 89.8 to 123.2. The highest number of leaflets was recorded by King Kumbra Tall followed by Comoros Red Tall, Comoros Green Tall and Panama Tall. The length of leaflet bearing portion and number of leaflets was lesser in dwarf accessions as reported by Ratnambal et al., (1995), Renuga (1999), Ratnambal et al., (2000), Arunachalam et al., (2005), Suchithra (2014), Perera et al., (2016a) and Jerard et al., (2017). In the present study also lesser number of leaflets was recorded in Sri Lankan Red Dwarf II. Hence this trait could be utilized for 
the identification of dwarf/tall palms during germplasm collection programmes. Total bunches on the crown was recorded and found to be highest (17.6 bunches) in Bari Narikel-II and lowest (9.6 bunches) in Comoros Green Tall. Average number of bunches on the crown with below fist size fruits varied from 2.5 in Sambava Tall to 4.0 in Comoros Tall, Uzirpur Tall, Bari Narikel-II and Sri Lankan
Yellow Dwarf II. The mean number of fruits below fist size per palm was the highest in Chinashukania Tall (321.9) while the accession Kayemkola Tall recorded the lowest number as 61.5. Higher number of fruits below fist size was also observed in Agailjhara Tall (266.4) and Bhagarapara Tall (236.0).

Table.1 Details of coconut accession selected for mean performance study

\begin{tabular}{|c|c|l|l|l|}
\hline Sl. No. & Code & \multicolumn{1}{|c|}{ Accession name } & Habit & \multicolumn{1}{|c|}{ Origin } \\
\hline $\mathbf{1}$ & SGT & Sambava Green Tall & Tall & Madagascar \\
\hline $\mathbf{2}$ & ST & Sambava Tall & Tall & Madagascar \\
\hline $\mathbf{3}$ & SLYD & $\begin{array}{l}\text { Sri Lankan Yellow Dwarf } \\
\text { II }\end{array}$ & Dwarf & Sri Lanka \\
\hline $\mathbf{4}$ & SLRD & Sri Lankan Red Dwarf II & Dwarf & Sri Lanka \\
\hline $\mathbf{5}$ & GTBT & Gon Thembili Tall II & Tall & Sri Lanka \\
\hline $\mathbf{6}$ & CMT & Comoros Tall & Tall & Madagascar \\
\hline $\mathbf{7}$ & CMRT & Comoros Red Tall & Tall & Comoros \\
\hline $\mathbf{8}$ & CMGT & Comoros Green Tall & Tall & Comoros \\
\hline $\mathbf{9}$ & BHT & Bagharpara Tall & Tall & Bangladesh \\
\hline $\mathbf{1 0}$ & KHT & Khairtala Tall & Tall & Bangladesh \\
\hline $\mathbf{1 1}$ & UZT & Uzirpur Tall & Tall & Bangladesh \\
\hline $\mathbf{1 2}$ & AGHT & Agailjhara Tall & Tall & Bangladesh \\
\hline $\mathbf{1 3}$ & RUPT & Rupdia Tall & Tall & Bangladesh \\
\hline $\mathbf{1 4}$ & KYKT & Kayemkola Tall & Tall & Bangladesh \\
\hline $\mathbf{1 5}$ & CHST & Chinashukania Tall & Tall & Bangladesh \\
\hline $\mathbf{1 6}$ & BNII & Bari Narikel-II & Tall & Bangladesh \\
\hline $\mathbf{1 7}$ & BNI & Bari Narikel-I & Tall & Bangladesh \\
\hline $\mathbf{1 8}$ & PBT & Pubail Tall & Tall & Bangladesh \\
\hline $\mathbf{1 9}$ & CBT & Coco Bleu Tall & Tall & Seychelles \\
\hline $\mathbf{2 0}$ & GRT & Guelle Rose Tall & Tall & Mauritius \\
\hline $\mathbf{2 1}$ & KKT & King Kumbra Tall & Tall & Maldives \\
\hline $\mathbf{2 2}$ & DUT & De La Reunion Tall & Tall & Reunion \\
\hline $\mathbf{2 3}$ & CNT & Chandan Nagar Tall & Tall & India, West \\
\hline & & & & \\
\hline $\mathbf{2 4}$ & TNT & Tinisera Tall & Tall & India, Orissa \\
\hline $\mathbf{2 5}$ & BT & Barajaguli Tall & Tall & India, West \\
Bengal
\end{tabular}


Table.2 mean performance of the coconut accessions for the vegetative growth characters

\begin{tabular}{|c|c|c|c|c|c|c|}
\hline $\begin{array}{l}\text { Sl. } \\
\text { No. }\end{array}$ & $\begin{array}{l}\text { Accessions } \\
\text { Code }\end{array}$ & $\begin{array}{c}\text { Trunk } \\
\text { girth at } \\
1.5 \mathrm{~m} \\
\text { height } \\
(\mathrm{cm})\end{array}$ & $\begin{array}{c}\text { Total } \\
\text { number } \\
\text { of leaves } \\
\text { on the } \\
\text { crown }\end{array}$ & $\begin{array}{l}\text { Length of } \\
\text { petiole } \\
\text { (cm) }\end{array}$ & $\begin{array}{c}\text { Length of } \\
\text { leaflet } \\
\text { bearing } \\
\text { portion }(\mathbf{c m})\end{array}$ & $\begin{array}{c}\text { Number } \\
\text { of paired } \\
\text { leaflets }\end{array}$ \\
\hline 1 & SGT & 75.2 & 36.1 & 132.3 & 387.7 & 113.0 \\
\hline 2 & ST & 84.3 & 27.0 & 140.3 & 419.2 & 111.0 \\
\hline 3 & SLYD & 72.3 & 25.3 & 130.7 & 312.7 & 104.0 \\
\hline 4 & SLRD & 62.0 & 27.0 & 105.7 & 260.7 & 89.8 \\
\hline 5 & GTBT & 62.5 & 26.2 & 139.7 & 365.0 & 104.7 \\
\hline 6 & CMT & 66.0 & 27.3 & 138.7 & 343.5 & 105.8 \\
\hline 7 & CMRT & 97.0 & 27.2 & 172.0 & 464.5 & 120.3 \\
\hline 8 & CMGT & 101.0 & 27.7 & 140.0 & 438.5 & 119.3 \\
\hline 9 & BHT & 91.3 & 29.7 & 147.1 & 365.8 & 108.2 \\
\hline 10 & KHT & 85.6 & 28.1 & 143.9 & 360.7 & 100.1 \\
\hline 11 & $\mathrm{UZT}$ & 79.7 & 28.4 & 142.6 & 364.4 & 103.0 \\
\hline 12 & AGHT & 81.2 & 28.2 & 145.3 & 376.4 & 112.2 \\
\hline 13 & RUPT & 82.7 & 30.3 & 149.4 & 407.8 & 105.5 \\
\hline 14 & KYKT & 80.5 & 28.4 & 134.3 & 371.7 & 107.1 \\
\hline 15 & CHST & 77.0 & 25.2 & 142.3 & 361.0 & 99.9 \\
\hline 16 & BNII & 102.7 & 30.5 & 156.5 & 440.7 & 113.1 \\
\hline 17 & BNI & 78.3 & 25.8 & 146.8 & 395.6 & 104.3 \\
\hline 18 & PBT & 70.7 & 25.3 & 123.7 & 393.3 & 100.9 \\
\hline 19 & CBT & 52.0 & 23.6 & 90.4 & 282.1 & 92.2 \\
\hline 20 & GRT & 80.7 & 26.7 & 142.7 & 415.8 & 111.7 \\
\hline 21 & KKT & 84.7 & 24.8 & 146.5 & 374.8 & 123.2 \\
\hline 22 & DUT & 90.0 & 31.3 & 143.7 & 410.0 & 110.5 \\
\hline 23 & CNT & 86.7 & 32.8 & 144.1 & 356.8 & 110.3 \\
\hline 24 & TNT & 87.0 & 30.0 & 132.4 & 406.5 & 115.3 \\
\hline 25 & BT & 77.8 & 29.4 & 142.3 & 401.9 & 117.9 \\
\hline 27 & PT & 81.8 & 33.7 & 147.1 & 398.8 & 119.3 \\
\hline 29 & WCT & 77.0 & 31.4 & 145.4 & 419.4 & 116.1 \\
\hline 30 & COD & 61.5 & 26.8 & 115.3 & 341.4 & 104.2 \\
\hline \multicolumn{2}{|r|}{ Mean } & 78.9 & 28.2 & 137.9 & 377.5 & 108.4 \\
\hline \multicolumn{2}{|r|}{ S. Ed } & 6.13 & 1.36 & 7.28 & 18.52 & 4.58 \\
\hline \multicolumn{2}{|c|}{ CD at $5 \%$} & 12.15 & 2.69 & 14.42 & 36.67 & 9.07 \\
\hline \multicolumn{2}{|c|}{ CV (\%) } & 9.5 & 5.9 & 6.5 & 6.0 & 5.2 \\
\hline
\end{tabular}


Table.3 Mean performance of the coconut accessions for the yield characters

\begin{tabular}{|c|c|c|c|c|c|c|}
\hline $\begin{array}{l}\text { Sl. } \\
\text { No. }\end{array}$ & $\begin{array}{l}\text { Accessions } \\
\text { Code }\end{array}$ & $\begin{array}{c}\text { Total } \\
\text { bunches on } \\
\text { the crown }\end{array}$ & $\begin{array}{l}\text { Number of } \\
\text { bunches } \\
\text { with fruits } \\
\text { below fist } \\
\text { size per } \\
\text { palm }\end{array}$ & $\begin{array}{l}\text { Number of } \\
\text { fruits below } \\
\text { fist size per } \\
\text { palm }\end{array}$ & $\begin{array}{l}\text { Number of } \\
\text { bunches } \\
\text { with fruits } \\
\text { above fist } \\
\text { size per } \\
\text { palm }\end{array}$ & $\begin{array}{c}\text { Total } \\
\text { number of } \\
\text { fruits above } \\
\text { fist size per } \\
\text { palm }\end{array}$ \\
\hline 1 & SGT & 14.1 & 3.50 & 139.5 & 10.7 & 131.5 \\
\hline 2 & $\mathrm{ST}$ & 11.5 & 2.50 & 72.5 & 9.0 & 69.6 \\
\hline 3 & SLYD & 13.3 & 4.00 & 87.0 & 9.3 & 62.6 \\
\hline 4 & SLRD & 11.0 & 3.33 & 79.5 & 7.6 & 67.3 \\
\hline 5 & GTBT & 13.3 & 3.50 & 115.3 & 10.8 & 56.0 \\
\hline 6 & CMT & 14.5 & 4.00 & 81.8 & 10.4 & 69.8 \\
\hline 7 & CMRT & 11.3 & 2.83 & 84.3 & 8.5 & 45.5 \\
\hline 8 & CMGT & 9.6 & 3.17 & 157.0 & 6.5 & 58.8 \\
\hline 9 & BHT & 11.1 & 3.00 & 236.0 & 8.2 & 85.9 \\
\hline 10 & KHT & 12.7 & 3.58 & 135.8 & 9.1 & 88.8 \\
\hline 11 & UZT & 16.6 & 4.00 & 176.8 & 12.3 & 87.2 \\
\hline 12 & AGHT & 13.5 & 3.25 & 266.4 & 10.3 & 75.1 \\
\hline 13 & RUPT & 15.1 & 3.83 & 146.5 & 11.8 & 90.4 \\
\hline 14 & KYKT & 14.6 & 3.33 & 61.5 & 11.3 & 84.8 \\
\hline 15 & CHST & 14.0 & 3.33 & 321.9 & 10.6 & 73.8 \\
\hline 16 & BNII & 17.6 & 4.00 & 307.1 & 13.6 & 107.0 \\
\hline 17 & BNI & 11.5 & 2.75 & 79.5 & 8.8 & 71.8 \\
\hline 18 & PBT & 10.8 & 3.33 & 100.1 & 7.8 & 47.1 \\
\hline 19 & $\mathrm{CBT}$ & 10.9 & 3.33 & 80.2 & 7.5 & 44.6 \\
\hline 20 & GRT & 12.0 & 2.67 & 71.0 & 9.3 & 45.8 \\
\hline 21 & KKT & 11.5 & 2.67 & 151.0 & 8.8 & 61.8 \\
\hline 22 & DUT & 13.1 & 3.17 & 180.3 & 10.1 & 49.3 \\
\hline 23 & CNT & 15.4 & 3.67 & 295.2 & 11.2 & 86.4 \\
\hline 24 & TNT & 14.3 & 3.17 & 127.7 & 11.1 & 69.7 \\
\hline 25 & BT & 12.2 & 3.67 & 206.1 & 8.5 & 88.4 \\
\hline 27 & PT & 17.0 & 3.67 & 116.6 & 13.5 & 97.2 \\
\hline 29 & WCT & 14.9 & 3.75 & 84.0 & 11.1 & 75.0 \\
\hline 30 & COD & 13.3 & 3.75 & 73.9 & 9.5 & 82.5 \\
\hline \multicolumn{2}{|r|}{ Mean } & 13.3 & 13.3 & 3.39 & 159.2 & 9.9 \\
\hline \multicolumn{2}{|r|}{ S. Ed } & 0.97 & 0.97 & 0.28 & 15.46 & 0.85 \\
\hline \multicolumn{2}{|c|}{ CD at $5 \%$} & 1.93 & 1.93 & 0.55 & 30.60 & 1.69 \\
\hline \multicolumn{2}{|r|}{ CV (\%) } & 9.0 & 9.0 & 10.2 & 11.9 & 10.5 \\
\hline
\end{tabular}


Table.4 Mean performance of coconut accessions for fruit quality characters

\begin{tabular}{|c|c|c|c|c|c|}
\hline $\begin{array}{c}\text { Sl. } \\
\text { No. }\end{array}$ & $\begin{array}{c}\text { Accessions } \\
\text { Code }\end{array}$ & $\begin{array}{c}\text { Weight of } \\
\text { whole fruit } \\
\text { (g) }\end{array}$ & $\begin{array}{c}\text { Husk to } \\
\text { whole nut } \\
\text { weight } \mathbf{( \% )}\end{array}$ & $\begin{array}{c}\text { Volume of } \\
\text { cavity (m) }\end{array}$ & $\begin{array}{c}\text { Weight of } \\
\text { fresh } \\
\text { kernel per } \\
\text { fruit } \mathbf{g})\end{array}$ \\
\hline $\mathbf{1}$ & SGT & 956.3 & 39.2 & 184.2 & 288.4 \\
\hline $\mathbf{2}$ & ST & 892.1 & 40.8 & 175.9 & 280.6 \\
\hline $\mathbf{3}$ & SLYD & 758.3 & 35.0 & 184.2 & 245.0 \\
\hline $\mathbf{4}$ & SLRD & 997.5 & 28.6 & 339.4 & 271.8 \\
\hline $\mathbf{5}$ & GTBT & 1121.4 & 28.5 & 287.9 & 438.3 \\
\hline $\mathbf{6}$ & CMT & 1021.7 & 37.5 & 219.4 & 357.9 \\
\hline $\mathbf{7}$ & CMRT & 1163.8 & 38.3 & 247.5 & 361.5 \\
\hline $\mathbf{8}$ & CMGT & 919.0 & 37.8 & 193.5 & 302.5 \\
\hline $\mathbf{9}$ & BHT & 1216.5 & 30.5 & 310.0 & 399.6 \\
\hline $\mathbf{1 0}$ & KHT & 1053.4 & 34.0 & 258.1 & 351.7 \\
\hline $\mathbf{1 1}$ & UZT & 984.9 & 34.5 & 246.9 & 329.9 \\
\hline $\mathbf{1 2}$ & AGHT & 1217.5 & 34.3 & 291.8 & 380.7 \\
\hline $\mathbf{1 3}$ & RUPT & 1163.6 & 37.6 & 268.4 & 345.1 \\
\hline $\mathbf{1 4}$ & KYKT & 1425.0 & 37.4 & 322.7 & 426.2 \\
\hline $\mathbf{1 5}$ & CHST & 1260.3 & 33.9 & 299.5 & 390.0 \\
\hline $\mathbf{1 6}$ & BNI & 1365.1 & 35.4 & 315.7 & 425.6 \\
\hline $\mathbf{1 7}$ & BNI & 1045.7 & 38.9 & 196.1 & 324.2 \\
\hline $\mathbf{1 8}$ & PBT & 1232.6 & 34.4 & 289.3 & 398.2 \\
\hline $\mathbf{1 9}$ & CBT & 483.0 & 35.1 & 168.3 & 193.3 \\
\hline $\mathbf{2 0}$ & GRT & 1734.7 & 47.4 & 283.1 & 449.0 \\
\hline $\mathbf{2 1}$ & KKT & 652.2 & 47.4 & 159.6 & 348.9 \\
\hline $\mathbf{2 2}$ & DUT & 923.1 & 36.4 & 246.9 & 335.2 \\
\hline $\mathbf{2 3}$ & CNT & 1165.4 & 36.4 & 274.6 & 379.2 \\
\hline $\mathbf{2 4}$ & TNT & 1058.4 & 41.2 & 213.0 & 349.8 \\
\hline $\mathbf{2 5}$ & BT & 1097.9 & 43.2 & 201.1 & 353.3 \\
\hline $\mathbf{2 7}$ & PT & 1209.1 & 36.9 & 258.2 & 389.3 \\
\hline $\mathbf{2 9}$ & WCT & 913.4 & 41.7 & 175.9 & 298.7 \\
\hline $\mathbf{3 0}$ & COD & 914.3 & 23.8 & 285.4 & 239.3 \\
\hline & Mean & $\mathbf{1 0 7 5 . 5}$ & $\mathbf{6 5 6 . 3}$ & $\mathbf{3 6 . 5}$ & $\mathbf{2 4 3 . 6}$ \\
\hline & S. Ed & $\mathbf{1 1 6 . 7 4}$ & $\mathbf{9 2 . 7 7}$ & $\mathbf{3 . 0 6}$ & $\mathbf{3 9 . 0 4}$ \\
\hline $\mathbf{C D ~ a t ~ 5 \%}$ & $\mathbf{2 3 1 . 1 5}$ & $\mathbf{1 8 3 . 7 0}$ & $\mathbf{6 . 0 7}$ & $\mathbf{7 7 . 2 9}$ \\
\hline & CV $(\mathbf{\%})$ & $\mathbf{1 3 . 3}$ & $\mathbf{1 7 . 3}$ & $\mathbf{1 0 . 3}$ & $\mathbf{1 9 . 6}$ \\
\hline & & & & & \\
\hline
\end{tabular}

Among the dwarfs, mean number of fruits below fist size was high in Sri Lankan Yellow Dwarf II (87.0) followed by Sri Lankan Red Dwarf II (79.5). Average number of bunches with above fist size fruits varied from 6.5 in
Comoros Green Tall and 13.6 in Bari NarikelII. The mean number of fruits above fist size per palm was the highest in Sambava Green Tall (131.5) while the accession Coco Bleu Tall recorded the lowest number (44.6). 
Among the dwarfs, it was high in Chowghat Orange Dwarf (82.5) followed by Sri Lankan Red Dwarf II (67.3). In present study, the significantly higher number of nuts per bunch, number of bunches per palm and total number of nuts per palm was recorded in the tall accessions (Table 3), Bari Narikel-II and Panama Tall, Uzirpur Tall and Chandan Nagar Tall. Similar results in West Coast Tall were reported by Potty et al., (1980), Suchithra (2014) and Jerard et al., (2017) on comparison of coconut varieties and different accession for number of bunches per palm. Satyabalan (1993) results showed that high female flower production and high setting per cent contributed more for higher yield. Pillai et al., (1991) and Thampan (1970) expressed this trait among coconut germplasm and it is a highly variable factor and is influenced by management practices, season, soil condition and manurial status, the varietal nature and the inherent yield potential of the palm.

Wide variation was observed for the nut characters among the studied accessions (Table 4), weight of whole fruit ranged from $483.0 \mathrm{~g}$ (Coco Bleu Tall) to $1734.7 \mathrm{~g}$ (Guelle Rose Tall) with a general mean of $1075.5 \mathrm{~g}$. Among the dwarfs, weight of whole fruit was higher in Sri Lankan Red Dwarf II (997.5 g) followed by Chowghat Orange Dwarf (914.3 g). Percentage of husk to whole nut weight ranged from $23.8 \%$ (Chowghat Orange Dwarf) to 47.4\% (Guelle Rose Tall and King Kumbra Tall), with grand mean $36.5 \%$. The range for fresh endosperm (kernel) weight was between $193.3 \mathrm{~g}$ (Coco Bleu Tall) to $449.0 \mathrm{~g}$ (Guelle Rose Tall). Among the tall accessions, Gon Thembli Tall II (438.3 g), followed by Kayemkola Tall (426.2 g) and Bari Narikel-II (425.6 g) recorded the higher weight of fresh kernel. Volume of the endosperm cavity was also found to vary widely between the accessions. Sri Lankan Red Dwarf II recorded higher cavity volume of $339.4 \mathrm{ml}$ followed by Kayemkola Tall
(322.7 ml), Bari Narikel-II (315.7 ml) and Bhagarpara Tall $(310.0 \mathrm{ml})$ and the minimum volume of cavity was recorded in King Kumbra Tall $(159.6 \mathrm{ml})$ followed by $184.2 \mathrm{ml}$ in the Sambava Green Tall.

From the study of mean performance of the accessions, it is difficult to postulate a single accessions with all the desirable traits combined together. However, based on growth and various yield attributing traits, the tall accessions Bari Narikel-II, Chandan Nagar Tall, Panama Tall, West Coast Tall, Rupdia Tall and Kayemkola Tall can be grouped as promising for the productivity traits. Among the dwarfs, Chowghat Orange Dwarf, Sri Lankan Red Dwarf II can be grouped as promising. Hence, this accession can be included in to the further breeding programme to develop the new for high yielding variety.

\section{Acknowledgment}

A first author is grateful to ICAR for awarding study leave to complete higher studies, Ph.D. Horticulture programme. Also to ICAR-CPCRI, RC, Kidu to provide the facility to conduct the research work smoothly.

\section{References}

Anon, 1995, IPGRI-Descriptors for coconut (Cocos nucifera L.). International plant genetic resources institute, Rome, Italy. p19.

Anon, 2011, Guidelines for the conduct of test for distinctiveness, uniformity and stability on coconut (Cocos nucifera L.). Plant Variety J. India. 5 (2\&3):3347.

Anon, 2017, Horticultural statistics at a Glance 2017, pp: 144-145. http://www.nhb.gov.in.

Arunachalam, V., Jerard, B. A., Damodaran, 
V., Ratnamball, M. J. and Kurnaranl, P. M., 2005. Phenotypic diversity of foliar traits in coconut germplasm. Genet. Resour. Crop Evol., 52: 1031-1037.

Iyer, R. D., 1980, Central Plantation Crop Research Institute. Annual Report, pp 11-13.

Jerard, B. A, 2002, Studies on the mean performance, variability, association analysis, stability and diversity in coconut (Cocos nucifera L.) genotypes. Ph.D. thesis submitted to Tamil Nadu Agricultural University, Coimbatore, India.

Jerard, B.A., Rajesh, M.K., Thomas, R.J., Niral, V. and Samsudeen, K., 2017, Island Ecosystems host rich diversity in coconut (Cocos nucifera): Evidences from Minicoy Island, India. Agricultural Research, 6 (3): 214-226.

Long, V. V., 1993, Coconut selection and breeding programme in Vietnam. In: Advances in Coconut Research and Development. M. K. Nair, H. H. Khan, P. Gopalasundaram and E. V. V. B. Rao (Eds.), Oxford and IBH Publishing Co. Pvt. Ltd. New Delhi, ppl07-114.

Nair, M. K. and Nampoothiri, K. V. K.,1993, Breeding for high yield in coconut. In: Advances in Coconut Research and Development M. K. Nair, H.H. Khan, P. Gopalasundaram and E.V.V.B. Rao (Eds.), Oxford and IBH Publishing Co. Pvt. Ltd. New Delhi, pp61-70.

Nampoothiri, K. U. K., Singh, H. P., Arulraj, S. and Thamban, C., 2000 Coconut cultivation technology. Coconut Development Board, Kochi.

Ohler, J. G., 1984, Coconut, tree of life. Plant Prod. Prot. Pap. 57, Food and Agr. Org. U. N., Rome.

Panse, V. G. and Sukhatme, P. V., 1961, Statistical methods for agricultural workers. ICAR, New Delhi. pp381.

Perera L., Russell, J. R., Provan, J. And
Powell, W., 2000, Use of microsatellite DNA markers to investigate the level of genetic diversity and population genetic structure of coconut (Cocos nucifera L.). Genome, 43: 15-21.

Perera, K. N. S., Herath, H. M. N. B., Attanayaka, D. P. S. T. G. and Perera, S. A. C. N., 2016, Evaluation of morphological diversity of conserved tall coconut (Cocos nucifera L.) germplasm in Sri Lanka. Tropical Agric. Res., 27 (4): 350-359.

Pieries, W. V. D., 1934, Studies on coconut palm. Tropical Agriculturist, 82: 75-97.

Pillai, R. V., Rao, E. V. V. B. and Kumaran, P. M., 1991, Characterization of coconut cultivars. In: Coconut Breeding and Management. E. G. Silas, M. Aravindakshan and A. I. Jose. (Eds), Kerala Agricultural University, Trichur, India. pp78-82.

Potty, N. N., Naik, B. J., Rajamony L. and Nambiar, P. R., 1980, Comparative performance of eight coconut varieties in red loam soil. Indian Coconut J., 11 (15): $1-2$.

Princy T., 2013 Performance evaluation of certain hybrids and parents of coconut (Cocos nucifera L.), M.Sc. Thesis submitted to Tamil Nadu Agricultural University, Coimbatore, India.

Purseglove, J. W. 1968. The origin and distribution of the coconut. Trop. Sci. 10 (4): 191-199.

Ratnamabal, M. J., Niral, V., Krishnan, M. and Ravi, K. N., 2000a, Coconut Descriptors, Part II, CD-ROM, C. P. C. R. I., Kasaragod, Kerala, India.

Ratnambal M. J., Nair, M. K., Muralidharan, K., Bhaskara Rao, E. V. V., Pillai, R. V., 1995, Coconut Descriptors Part 1. C. P. C. R. I., Kasaragod, Kerala, India, p197.

Ratnambal, M. J., Arunachalam, V., Jerard, B. A., Rizwal, S. and Damodaran V., 2002, Biometric analysis of diversity in 
Pacific Ocean coconut populations. CORD, XVIII (2):74-88.

Renuga, M., 1999, Studies on indexing the economic characters of varieties and hybrids for the genetic improvement of coconut (Cocos nucifera L.) through selection. Ph. D. Thesis submitted to Tamil Nadu Agricultural University, Coimbatore, India.

Samsudeen, K., Thamban, C. Niral, V., Augustine Jerard, B., Rajesh, M. K., Manjula, C., Devadas, K. and Anitha K., 2013, In situ approach for rapid characterization to aid on farm conservation of coconut germplasm - A case study of two ecotypes from West coast of India. J. Pl. Crops, 41 (3): 357363.

Satyabalan, K., 1993, Yield variation in West Coast Tall coconut palms. Indian Coconut J., December, pp5-8.

Suchithra, M., 2014, Stuides on performance of certain indigenous and exotic coconut genotypes (Cocos nucifera L.). M.Sc. Thesis submitted to Tamil Nadu Agricultural University, Coimbatore, India.

Thampan, P. K., 1970, Hybrid palm. Cocon. Bull., 1: 3-5.

\section{How to cite this article:}

Khadke, G.N., V. Niral, M.S. Kulkarni, N.K. Hegde, N. Sandhyarani and Naika, M.B.N. 2019. Mean Performance of the National and International Coconut Accessions for the Yield Attributing and Nut Quality Traits. Int.J.Curr.Microbiol.App.Sci. 8(02): 2597-2606.

doi: https://doi.org/10.20546/ijcmas.2019.802.302 